\title{
Numerical Model of Leachate Recirculation in Bioreactor Landfills with High Kitchen Waste Content
}

\author{
Peng Zhang $\mathbb{D}^{D}$, Hailong Liu *D, Xingyao Jiang, Hao Lv, Chunyi Cui and Zhen Huyan \\ Department of Civil Engineering, Dalian Maritime University, Dalian 116026, China; \\ peng.zhang47@dlmu.edu.cn (P.Z.); j1120190354@dlmu.edu.cn (X.J.); 1120200360lh@dlmu.edu.cn (H.L.); \\ cuichunyi@dlmu.edu.cn (C.C.); huyanzhen@dlmu.edu.cn (Z.H.) \\ * Correspondence: liuhailong@dlmu.edu.cn
}

check for updates

Citation: Zhang, P.; Liu, H.; Jiang, X.; Lv, H.; Cui, C.; Huyan, Z. Numerical Model of Leachate Recirculation in Bioreactor Landfills with High Kitchen Waste Content. Water 2021, 13, 1750. https://doi.org/10.3390/ w13131750

Academic Editor: William F. Ritter

Received: 14 May 2021

Accepted: 21 June 2021

Published: 24 June 2021

Publisher's Note: MDPI stays neutral with regard to jurisdictional claims in published maps and institutional affiliations.

Copyright: (C) 2021 by the authors Licensee MDPI, Basel, Switzerland. This article is an open access article distributed under the terms and conditions of the Creative Commons Attribution (CC BY) license (https:// creativecommons.org/licenses/by/ $4.0 /)$.

\begin{abstract}
Surface spraying, horizontal trenches, and vertical wells are the most common leachate recirculation system used at landfills in engineering practice. In order to quantify the efficiency of the three aforementioned recirculation systems, a hydro-biochem-mechanical-coupled model was developed in the present work, which can describe hydrodynamic and biochemical behaviors in food-waste-rich landfills. A typical landfill cell was modeled in COMSOL. The results indicate that leachate recirculation can accelerate the decomposition of municipal solid waste (MSW) with foodrich waste content, relieving acidification, improving gas generation efficiency, and consequently, increasing the early settlement in landfills.
\end{abstract}

Keywords: municipal solid waste; landfill; leachate treatment; coupled model; numerical simulation

\section{Introduction}

Disposing of municipal solid waste (MSW) has been a worldwide environmental issue for decades. Landfilling is a commonly used MSW management method all around the world [1,2]. Due to the biochemical reaction of degradable components in MSW, the releasing of polluted leachate and landfill gas will be a long-term process that may take years even decades [3-6]. Therefore, it is of great necessity to reduce landfill emissions so as to avoid long-term environmental risks [7].

Conventional sanitary landfills are designed without providing any processes to influence MSW degradation. The degradation rate of MSW is slow in the closed anaerobic environment in conventional landfills, which results in a quite long time of landfill stabilization process [8]. To fasten the stabilization of conventional landfills, a variety of techniques have been proposed in engineering practice. The bioreactor landfill (BL) concept has been proposed as a means to improve the degradation environment in landfills by using leachate recirculation (LR) $[9,10]$. The test-cell and full-scale studies have indicated the following several advantages of BL: (1) the volume of leachate to be treated by biochemical methods is reduced; (2) the leachate quality is improved with nutrients and enzymes evenly distributed; (3) landfill gas generation and settlement stabilization are accelerated [11-19].

Surface spraying, horizontal trenches, and vertical wells are the most common LR system used at landfills in engineering practice [20]. In order to achieve optimal design of the LR system in a bioreactor landfill, it is necessary to investigate the distribution and transport pattern of leachate and landfill gas in landfills. Although several mathematical models have been proposed to interpret the gas transport in landfills [21-24], these models mainly focus on gas transport, ignoring the influences of liquid flow on landfill gas collection. Khire and Haydar [25] established a 2D finite element model to investigate the hydraulic behaviors of injected leachate in drainage blankets. Jain et al. [26] summarized the influences of several parameters on the characteristics of the MSW and offered charts for designing an LR system. Reddy et al. [27] developed a two-dimensional-coupled model to characterize the hydro-bio-mechanical process of both conventional landfills and BLs. 
Feng et al. [28] employed a 3D modeling approach to evaluate the interactions between leachate flow and landfill gas transportation.

Based on the proposed models, several computation platforms are also programmed for engineering applications. For instance, White et al. [29] initially developed a program with the name of landfill degradation and transport (LDAT) to synthetically consider the behavior and interaction between the content of a landfill, including solid, liquid (leachate), and released gas. MODUELO [30] is another software for modeling the complicated biodegradation of a landfill.

Even though several models have been developed in the past decades, not much attention has been paid to the bioreactor landfills with food-waste-rich content. As a matter of fact, MSWs in developing countries (e.g., China), is featured by a large portion of foodtype waste and high initial moisture content [31]. At the early stage of stabilization, landfills with high food waste contents are generally associated with a high leachate production rate and initial moisture content due to the rapid hydrolysis of kitchen waste components after disposal. The injection of leachate could increase pore pressure inside landfills, and it may cause slope failure or high leachate levels in landfills with high kitchen waste content [32-35].

The paper focused on the hydraulic behaviors of leachate recirculation in bioreactor landfills with high kitchen waste content by establishing a hydro-biochem-mechanicalcoupled model (HBM-coupled model). The effects of three LR systems (surface spraying, horizontal trenches, and vertical wells) were investigated via the HBM-coupled model.

\section{Materials and Methods}

\subsection{Hydro-Biochem-Mechanical-Coupled Model}

The governing equations of the HBM-coupled model include the leachate flow model, the landfill gas transportation model, the skeleton compression model of MSW, and the solute migration model. Two Richards equations were used to describe the transport behaviors of leachate and landfill gas in landfills, respectively. According to the mass conservation of liquid and gas for a unit volume $\Delta V$ of MSW, the models of leachate flow and landfill gas transportation are determined as follows:

$$
\begin{gathered}
\rho_{\mathrm{w}} \frac{\partial}{\partial t}(n S \Delta V)=\rho_{\mathrm{w}} \nabla \cdot\left[\frac{\mathbf{k}_{\mathrm{iw}} k_{r w}}{\mu_{\mathrm{w}}} \nabla \cdot\left(p_{\mathrm{w}}+\rho_{\mathrm{w}} g z\right)\right] \Delta V+f_{\mathrm{w}} \Delta V \\
\frac{\partial}{\partial t}\left[\rho_{\mathrm{g}} n(1-S) \Delta V\right]=\nabla \cdot\left[\frac{\mathbf{k}_{\mathrm{ig}} k_{\mathrm{rg}}}{\mu_{\mathrm{g}}} \nabla \cdot\left(\rho_{\mathrm{g}} p_{\mathrm{g}}\right)\right] \Delta V+f_{\mathrm{g}} \Delta V
\end{gathered}
$$

where $n$ is the porosity of MSW; $S$ is the saturation; $\rho_{\mathrm{w}}$ and $\rho_{\mathrm{g}}$ are the density of leachate and landfill gas, respectively; $\nabla$. is the partial differential operator; $\mathbf{k}_{\mathbf{i w}}$ and $\mathbf{k}_{\mathbf{i g}}$ are the intrinsic permeabilities for leachate and landfill gas, respectively; $k_{\mathrm{rw}}$ and $k_{\mathrm{rg}}$ are the relative permeability functions for leachate and landfill gas, respectively; $\mu_{\mathrm{W}}$ and $\mu_{\mathrm{g}}$ are the dynamic viscosities; $p_{\mathrm{W}}$ is the pore pressure of liquid; $p_{\mathrm{g}}$ is the pore pressure of landfill gas; $f_{\mathrm{W}}$ is the source term due to leachate generation with the hydrolysis of kitchen waste; $f_{\mathrm{g}}$ is the source term due to landfill gas generation during decomposition.

The relative permeabilities of leachate and landfill gas are commonly related to liquid saturation in landfills. The unsaturated hydraulic properties of MSW can be described by employing the van Geunchten model [36,37] as follows:

$$
\begin{gathered}
S_{E}=\frac{S-S_{r}}{S_{S}-S_{r}}=\left(1+|\alpha S|^{\frac{1}{1-m}}\right)^{-m} \\
k_{r w}=S_{E}^{1 / 2}\left[1-\left(1-S_{E}^{1 / m}\right)^{m}\right]^{2} \\
k_{r g}=\left(1-S_{E}\right)^{1 / 2}\left(1-S_{E}^{1 / m}\right)^{2 m}
\end{gathered}
$$


where $S_{E}$ is the effective saturation; $S_{S}$ is the maximum saturation of MSW; $S_{r}$ is the residual saturation; $s$ is the suction, $s=p_{\mathrm{g}}-p_{\mathrm{w}} ; \alpha$ and $m$ are dimensionless constants for the van Geunchten model.

The hydraulic models for leachate (Equation (1)) and landfill gas (Equation (2)) can be further expressed as

$$
\begin{gathered}
-\rho_{\mathrm{w}} n \frac{\partial S}{\partial s} \frac{\partial p_{\mathrm{w}}}{\partial t}+\rho_{\mathrm{w}} n \frac{\partial S}{\partial s} \frac{\partial p_{g}}{\partial t}+\rho_{\mathrm{w}} S \frac{\partial n}{\partial t}=\rho_{\mathrm{w}} \nabla \cdot\left[\frac{\mathbf{k}_{\mathbf{i w}} k_{r w}}{\mu_{\mathrm{w}}} \nabla \cdot\left(p_{w}+\rho_{w} g z\right)\right]+f_{w} \\
\rho_{g} n \frac{\partial S}{\partial s} \frac{\partial p_{w}}{\partial t}+\left[\frac{n(1-S) M}{R T}-\rho_{g} n \frac{\partial S}{\partial s}\right] \frac{\partial p_{g}}{\partial t}+\rho_{g}(1-S) \frac{\partial n}{\partial t} \\
=\nabla \cdot\left[\frac{\mathbf{k}_{\mathbf{i g}} k_{\mathrm{rg}}}{\mu_{\mathrm{g}}} \nabla \cdot\left(\rho_{g} p_{g}\right)\right]+f_{g}
\end{gathered}
$$

where $M$ is the average molecular weight of mixture gas in landfills; $R$ is the ideal gas constant; $T$ is temperature.

The anaerobic degradation process of MSW can be divided into two stages simplified: the hydrolysis of cellulolytic matter (which provides most of the methane generation potential of MSW [38]) and methanogenesis [39]. The decomposition process can be idealized as Equation (8). In the hydrolysis stage, the cellulolytic matter is converted into typical volatile fatty acids (VFA, such as acetic acid), hydrogen $\left(\mathrm{H}_{2}\right)$, and carbon dioxide $\left(\mathrm{CO}_{2}\right)$. There is a large amount of intraparticle water in food waste, which is the primary source of leachate in food-waste-rich landfills. $\lambda_{\text {iw }}$ is the weight ratio of intraparticle water in food waste to cellulolytic matter, which can be estimated by composition and initial moisture content in fresh MSW [40]. The VFA generated during the hydrolysis stage is consumed by methanogen and transformed into landfill gas $\left(\mathrm{CH}_{4}\right.$ and $\left.\mathrm{CO}_{2}\right)$.

$$
\begin{aligned}
& \mathrm{C}_{6} \mathrm{H}_{10} \mathrm{O}_{5}\left(\lambda_{i w} \mathrm{H}_{2} \mathrm{O}\right)+5 \mathrm{H}_{2} \mathrm{O} \stackrel{\text { Hydrolysis }}{\rightarrow} \mathrm{CH}_{3} \mathrm{COOH}+8 \mathrm{H}_{2}+4 \mathrm{CO}_{2}+\lambda_{i w} \mathrm{H}_{2} \mathrm{O} \\
& \text { Methanogenesis } \\
& \stackrel{\longrightarrow}{\rightarrow} 3 \mathrm{CH}_{4}+3 \mathrm{CO}_{2}+\left(4+\lambda_{i w}\right) \mathrm{H}_{2} \mathrm{O}
\end{aligned}
$$

The source terms of leachate and landfill gas generation during the stabilization process are determined by a two-stage anaerobic degradation model of MSW [41]. The generation of VFA (that is acetic acid $\mathrm{CH}_{3} \mathrm{COOH}$ in Equation (8)) is determined by the actual hydrolysis rate of cellulolytic matter in MSW. The generation rate of VFA, $m_{\mathrm{VFA}}$, can be simplified as a constant $b$ ( $b$ is the maximum hydrolysis rate under optimal degradation conditions) with correction functions to reflect the influences of degradation conditions and substrate content [39], which can be expressed as follows:

$$
\begin{gathered}
\frac{\partial m_{\mathrm{VFA}}}{\partial t}=S_{E} f_{i h}\left(m_{c}\right) f_{i h}\left(c_{1}\right) b \\
f_{i h}\left(m_{c}\right)=1-\left(\frac{m_{\mathrm{c}}\left(t_{0}\right)-m_{\mathrm{c}}(t)}{m_{\mathrm{c}}\left(t_{0}\right)}\right)^{a} \\
f_{i h}\left(c_{1}\right)=\exp \left(-k_{\mathrm{h}} c_{1}\right)
\end{gathered}
$$

where $m_{\mathrm{c}}\left(t_{0}\right)$ is the initial cellulolytic matter content in a unit mass of MSW; $m_{\mathrm{c}}(t)$ is the cellulolytic matter content at time $t ; a$ and $k_{\mathrm{h}}$ are the inhibition constants of the substrate and VFA, respectively; $c_{1}$ is the VFA concentration.

The consumption of VFA is linearly related to the growth of methanogen, $m_{\mathrm{MB}}$, which can be described by the Monod equation (Equation (13)) [42]. The accumulation rate of VFA in leachate, $f_{\mathrm{c}}{ }^{1}$, is expressed with Equation (12) as follows:

$$
\begin{aligned}
f_{c}^{1} & =\frac{\partial m_{\mathrm{VFA}}}{\partial t}-\frac{1}{Y} \frac{\partial m_{\mathrm{MB}}}{\partial t} \\
\frac{\partial m_{\mathrm{MB}}}{\partial t} & =\frac{S_{\mathrm{E}} k_{\mathrm{max}} c_{1} c_{2}}{k_{\mathrm{s}}+c_{1}} \exp \left(-k_{\mathrm{m}} c_{1}\right)
\end{aligned}
$$


where $k_{\max }$ is the optimal growth rate of methanogen; $k_{\mathrm{m}}$ is the inhibition constant of methanogen content; $k_{\mathrm{S}}$ is the half-saturation constant; $c_{2}$ is the concentration of methanogen; $Y$ is the coefficient constant of substrate yield.

Methanogen continues to grow and decay during the whole degradation stabilization in landfills. The decay rate of methanogen is related to the size of the methanogen population, which can be simplified as a function of methanogen concentration (Equation (15)) [37] The accumulation of methanogen in landfills, $f_{\mathrm{c}}{ }^{2}$, can be expressed with Equation (14) as follows:

$$
\begin{gathered}
f_{c}^{2}=\frac{\partial m_{\mathrm{MB}}}{\partial t}-\frac{\partial m_{\mathrm{MB}}^{\mathrm{d}}}{\partial t} \\
\frac{\partial m_{\mathrm{MB}}^{\mathrm{d}}}{\partial t}=S_{\mathrm{E}} k_{\mathrm{d}} c_{2}
\end{gathered}
$$

where $k_{\mathrm{d}}$ is the decay rate constant of methanogen; $c_{2}$ is the methanogen concentration.

Intraparticle water release from food waste contributes to most of the leachate production at the hydrolysis stage [3]. The liquid source term of the hydraulic model is described as the release rate of intraparticle water. In this paper, landfill gas was considered as the mixture of $\mathrm{CO}_{2}$ and $\mathrm{CH}_{4}$ produced by degradation. The sum of $\mathrm{CO}_{2}$ and $\mathrm{CH}_{4}$ generation rate was the gas source term of the hydraulic model. The source terms of both liquid and gas can be calculated according to the mass conservation in the biochemical reaction equation (Equation (8)), the generation rate for both VFA and methanogen (Equations (9) and (13)). The source terms of hydraulic models are listed as follows:

Leachate generation during the hydrolysis period:

$$
f_{\mathrm{w}}=\beta_{1} \frac{\partial m_{\mathrm{VFA}}}{\partial t}=\beta_{1} S_{E} f_{i h}\left(m_{c}\right) f_{i h}\left(c_{1}\right) b
$$

Landfill gas generation with methanogenesis:

$$
f_{\mathrm{g}}=\beta_{2} \frac{\partial m_{\mathrm{MB}}}{\partial t}=\frac{\beta_{2} S_{\mathrm{E}} k_{\max } c_{1} c_{2}}{Y\left(k_{\mathrm{s}}+c_{1}\right)} \exp \left(-k_{\mathrm{m}} c_{1}\right)
$$

The leachate generation and landfill gas release are related to the content of VFA and methanogen. It is necessary to investigate the migration of contaminants with leachate flow to estimate the hydraulic behaviors in bioreactor landfills with high kitchen waste content accurately. The mass conservation equation for solutes (i.e., VFA and methanogen) is also established by neglecting the effects of adsorption/desorption. The governing equation of the solute migration model was proposed as follows:

$$
\begin{aligned}
& n S \frac{\partial c_{i}}{\partial t}-n c_{i} \frac{\partial S}{\partial s} \frac{\partial p_{w}}{\partial t}+n c_{i} \frac{\partial S}{\partial s} \frac{\partial p_{g}}{\partial t}+c_{i} S \frac{\partial n}{\partial t} \\
& \quad=-\nabla \cdot\left(c_{i} \mathbf{v}_{w}\right)+\nabla \cdot\left(\mathbf{D}_{i} \nabla c_{i}\right)+f_{c}^{i}
\end{aligned}
$$

where $\mathbf{v}_{w}$ is the fluid velocity of leachate; $\mathbf{D}_{i}$ is diffusion coefficient matrix for both VFA $(i=1)$ and methanogen $(i=2)$, respectively; $f_{c}{ }^{i}$ is the source term of VFA $(i=1)$ or methanogen $(i=2)$, which can be determined by Equations (12) and (14).

The compression of MSW consists of (1) primary compression due to the applied load from subsequently landfilled waste and (2) long-term degradation compression and mechanical creep [43,44]. The results of laboratory compression tests on MSW with high kitchen waste content indicated that the total compression strain of landfills can be assumed to be dependent on only the final applied load and the degree of degradation (usually expressed as a function of elapsed time) [44]. A compression model of food-waste-rich landfills was proposed based on the above compression mechanism. This compression model can consider the compressibility of MSW decrease with stabilization process of landfills, and the compression strain of landfill body can be described as follows:

$$
\varepsilon_{V}\left(\sigma^{\prime}, t\right)=C_{C}{ }^{\prime} \log \frac{\alpha_{m} \sigma^{\prime}}{\sigma_{0}}\left[s_{b \infty}+\left(C_{C \infty}{ }^{\prime}-C_{C}{ }^{\prime}\right) \log \frac{\alpha_{s} \sigma^{\prime}}{\sigma_{0}}\right]\left\{1-\exp \left[-\beta_{s}\left(t-t_{P}\right)\right]\right\}
$$




$$
\begin{gathered}
\sigma^{\prime}=\sigma_{T}-\left[S p_{\mathrm{w}}+(1-S) p_{\mathrm{g}}\right] \\
\alpha_{m}=c_{m 1} \frac{m_{\mathrm{c}}(t)}{m_{\mathrm{c}}\left(t_{0}\right)} \\
\beta_{m}=c_{m 2}\left[\frac{m_{\mathrm{c}}\left(t_{0}\right)-m_{\mathrm{c}}(t)}{m_{\mathrm{c}}\left(t_{0}\right)}\right]^{N_{m}}
\end{gathered}
$$

where $\varepsilon_{v}\left(\sigma^{\prime}, t\right)$ is the volumetric compression strain of MSW at time $t$ with the effective overburden stress, $\sigma^{\prime} ; C_{C}{ }^{\prime}$ and $C_{C \infty}{ }^{\prime}$ are modified primary compression ratios for fresh waste and degraded waste, respectively; $\sigma^{\prime}$ is the effective overburden stress, which can be calculated according to total stress $\sigma_{T}$ and pore liquid/gas pressure; $\sigma_{0}$ is preconsolidation pressure; $s_{\mathrm{b} \infty}$ is the sum of final volumetric strains of degradation compression and mechanical creep under stress $\sigma_{0} ; t_{p}$ is the completion time of the primary compression; $\alpha_{m}$ and $\beta_{m}$ are the functions related to degradable component content, which are used to describe compressibility of MSW decrease with decomposition; $c_{m 1}, c_{m 2}$, and $N_{m}$ are the compression rate constants.

The change of pore volume in MSW consists of (1) a decrease in the void volume, attributable to applied loading, creep, and decomposition compression and (2) a change in solid skeleton volume due to the solid mass loss of degradable component content. The change of porosity of MSW can be expressed as follows:

$$
\frac{\partial n}{\partial t}=\frac{\partial \varepsilon_{\mathrm{v}}(\sigma l, t)}{\partial t}+\frac{1}{\rho_{m}} \frac{\partial m_{\mathrm{c}}(t)}{\partial t}
$$

where $\rho_{m}$ is the average density of degradable component content, which is assumed as a constant in this manuscript.

\subsection{Numerical Cases of Leachate Recirculation in a Typical Kitchen-Waste-Rich Bioreactor Landfill Cell}

Surface spraying, vertical well, and horizontal trenches are the most common leachate recirculation system used at bioreactor landfills in engineering practice. Three hypothetical landfill cells of the same size (10 m wide and $10 \mathrm{~m}$ high) were established to investigate the effects of different leachate recirculation systems in bioreactor landfills with high food waste content. The schematic diagram of the numerical model is shown in Figure 1. MSWs in different cases were assumed to have the same initial conditions and primary compression due to the applied load from placed MSW has been completed. The bottom leachate drainage systems of these models were set up so that clogging would not occur, which means a free-draining boundary of leachate. The concentration boundaries for both VFA and methanogen were set as the open boundary. The vertical well for leachate recirculation in case 2 had a radius of $0.2 \mathrm{~m}$ and a depth of $5 \mathrm{~m}$, and the size of the horizontal trench in case 3 was $1 \mathrm{~m} \times 1 \mathrm{~m}$. The leachate recirculation boundaries (i.e., the top boundary of landfill cell in case of surface spraying, the inner wall of a vertical wall, or horizontal trench in case 2 and 3, respectively) were set to free flow for landfill gas. The daily amounts of leachate injection were the same, that is, $150.34 \mathrm{~kg} / \mathrm{d}$, and the injection rates of leachate for the three cases were converted according to the daily recirculation amount. The effects of the above three leachate recirculation systems were evaluated via the HBM-coupled model. The HBM-coupled model proposed in this paper was solved by employing the PDE module, Darcy's law module, and the transport of diluted species in the porous media module of COMSOL Multiphysics 5.3. The parameter values of the HBM-coupled model are listed in Table 1. The initial contents of MSW components were set up based on typical components of fresh waste in China $[40,45]$. The biochemical kinetic parameter values were used according to the research of Meima et al. [46] and Chen et al. [47]. The hydraulic parameter values were determined according to the laboratory test results of MSW with high food waste content $[28,48]$. Mechanics parameters were recommended values based on a series of compression tests of kitchen-waste-rich MSW [44,49-51], and 
part of mechanics parameters (such as $c_{m 1}, c_{m 2}$, and $N_{m}$ ) were obtained by fitting from test results of Chen et al. [44].

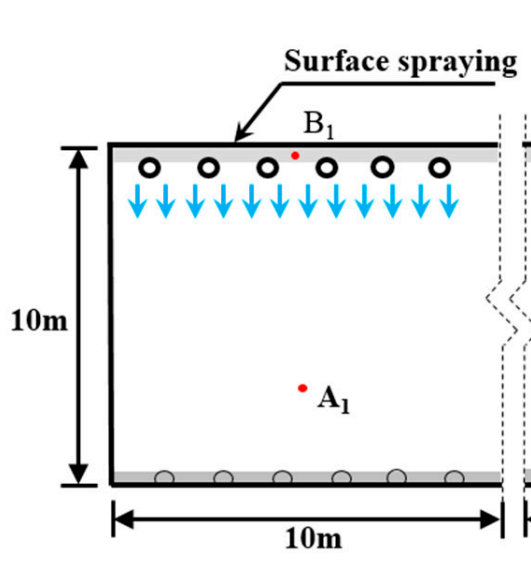

Case 1

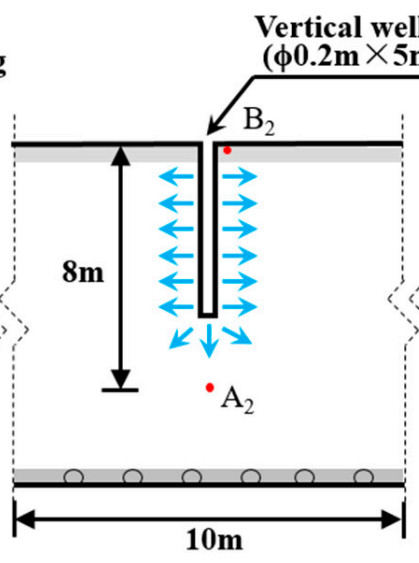

Case 2

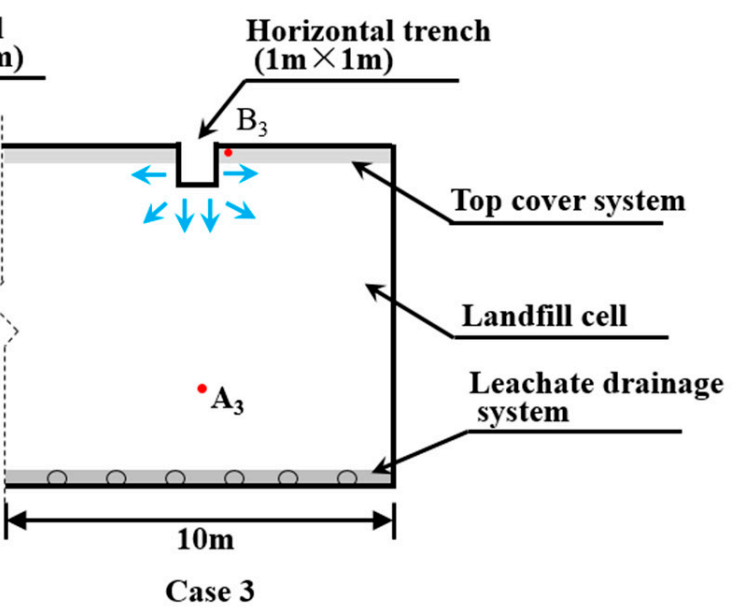

Initial conditions:

- Moisture content: $\mathbf{0 . 4 5}$

- Pore gas pressure: 0 kPa

- VFA concentration: 0 g/L

- Methanogen concentration: $0.24 \mathrm{~g} / \mathrm{L}$ (landfill); $0.8 \mathrm{~g} / \mathrm{L}$ (treated leachate for recirculation)

Figure 1. Hypothetical cases of bioreactor landfill cells using different leachate recirculation systems.

Table 1. Parameter values of HBM-coupled model.

\begin{tabular}{|c|c|c|}
\hline Parameter & Values & Reference \\
\hline $\begin{array}{c}m_{\mathrm{c}}(\text { dry basis, } w t / w t, \%) \\
m_{1}(\text { dry basis, } w t / w t, \%) \\
\lambda_{\text {iw }}\left(\mathrm{g} / \mathrm{m}^{3} / \mathrm{d}\right)\end{array}$ & $\begin{array}{c}21.4 \\
13.9 \\
60\end{array}$ & $\begin{array}{l}\text { Chen et al. [40]; } \\
\text { He et al. [45] }\end{array}$ \\
\hline $\begin{array}{c}b\left(\mathrm{~g} / \mathrm{m}^{3} / \mathrm{d}\right) \\
k_{\mathrm{h}}\left(\mathrm{m}^{3} / \mathrm{g}\right) \\
a \\
k_{\max }\left(\mathrm{d}^{-1}\right)\end{array}$ & $\begin{array}{c}250 \text { (kitchen waste), } \\
100 \text { (other) } \\
0.1 \\
2.8 \\
0.1\end{array}$ & $\begin{array}{l}\text { Meima et al. [46]; } \\
\text { Chen et al. [47] }\end{array}$ \\
\hline $\begin{array}{c}k_{\mathrm{m}}\left(\mathrm{m}^{3} / \mathrm{g}\right) \\
k_{\mathrm{d}}\left(\mathrm{d}^{-1}\right) \\
k_{\mathrm{s}}\left(\mathrm{g} / \mathrm{m}^{3}\right) \\
Y\end{array}$ & $\begin{array}{c}0.06 \\
0.01 \\
4 \\
0.08\end{array}$ & $\begin{array}{l}\text { Meima et al. [46]; } \\
\text { Chen et al. [47] }\end{array}$ \\
\hline $\begin{array}{c}k_{\mathrm{i}}\left(\mathrm{m}^{2}\right) \\
\mu(\mathrm{kg} / \mathrm{m} / \mathrm{s}) \\
\alpha \\
m \\
S_{\mathrm{s}} \\
S_{\mathrm{r}} \\
D_{l, c 1}\left(\mathrm{~m}^{2} / \mathrm{s}\right) \\
D_{l, c 2}\left(\mathrm{~m}^{2} / \mathrm{s}\right)\end{array}$ & $\begin{array}{c}6 \times 10^{-12} \\
1 \times 10^{-3}\left(\mu_{\mathrm{w}}\right), 1.4 \times 10^{-5} \\
\left(\mu_{\mathrm{g}}\right) \\
0.88 \\
1.6 \\
0.95 \\
0.2 \\
1.19 \times 10^{-9} \\
1 \times 10^{-9}\end{array}$ & $\begin{array}{c}\text { Feng et al. [28]; } \\
\text { Xu et al. [48] }\end{array}$ \\
\hline
\end{tabular}


Table 1. Cont.

\begin{tabular}{ccc}
\hline Parameter & Values & Reference \\
\hline$n_{0}$ & 0.75 & Li et al. [49] \\
\hline$C_{\mathrm{C}^{\prime}}$ & 0.205 & Gao et al. [50] \\
$C_{\mathrm{C}^{\prime}}$ & 0.074 & \\
$s_{\mathrm{b} \infty}$ & 0.23 & Chen et al. [44] \\
$\beta_{\mathrm{s}}\left(\mathrm{d}^{-1}\right)$ & 0.2 & \\
$\sigma_{0}(\mathrm{kPa})$ & 13 & Liu et al. [51] \\
\hline$\rho_{d}\left(\mathrm{kN} / \mathrm{m}^{3}\right)$ & 34 & \\
\hline$c_{m 1}$ & 1.3 & \\
$c_{m 2}$ & 2.1 & \\
$N_{m}$ & 1.75 & \\
\hline
\end{tabular}

\section{Results and Discussion}

\subsection{Acceleration of Landfill Stabilization Process}

Cellulolytic matter in degradable components provides most of the landfill gas generation potential of MSW [38]. The ratio of cellulose to lignin content (C/L) in MSW is commonly used as an evaluation index of landfill stabilization [52]. The $\mathrm{C} / \mathrm{L}$ decreases gradually with the hydrolysis of cellulolytic matter. As shown in Figure 2, the C/L of MSW close to the leachate recirculation system decreases significantly at $1000 \mathrm{~d}$ after the start of leachate injection. For case 1, surface spraying makes a relatively uniform decrease in the degradation degree of shallow MSW in the landfill cell. On the other hand, the accelerated degradation areas in landfill are mainly located near the inner walls of the vertical well or the horizontal trench for the case 2 and 3, respectively. The effects of applying different leachate recirculation systems on the acceleration of the stabilization process of MSW in a deep layer of the landfill are close. The variation of average C/L of MSW below the leachate recirculation system (see in Figure 3) indicates that leachate recirculation has a more pronounced accelerating effect on MSW degradation in the first 500 days, with average C/L decreasing from an initial 3.50 to 2.90 (case 1), 2.83 (case 2) and 2.78 (case 3), respectively. Vertical well makes the injected leachate contact with MSW of different depths in the landfill cell, and the acceleration effect on the stabilization process of landfill is better than other leachate recirculation systems at the early stage.

\subsection{Moisture Distribution in Landfill Cell and Removal of VFA in Leachate}

Leachate injection can increase moisture content in landfills directly. At the same time, the accelerated hydrolysis of MSW caused by leachate recirculation will release more intraparticle water in the cellulolytic matter of MSW, which will result in a further increase of moisture content. As shown in Figure 4, the maximum saturation in landfills increases from the initial $45 \%$ to $57 \%$ (case 1), $59 \%$ (case 2), and $62 \%$ (case 3), respectively. This manuscript assumed that the daily total amount of leachate injected by using different recirculation systems is the same. The horizontal trench (case 3) has the largest injection rate of leachate because the area for injection in the horizontal trench is the smallest among these three cases; therefore, the increase of saturation in case 3 is the most significant. The injection of treated leachate provides a large amount of methanogen to landfills, which can consume the VFA in fresh leachate generated by fast hydrolysis of kitchen waste effectively. The peak concentration of VFA in leachate is lower than $2 \mathrm{~g} / \mathrm{L}$, and case 2 has the lowest concentration of VFA (Figure 5). The removal of VFA in leachate means no remarkable acid inhibition of MSW degradation will occur in the bioreactor landfills with high kitchen waste content, as evidenced by the experimental results of Zhan et al. [3]. 

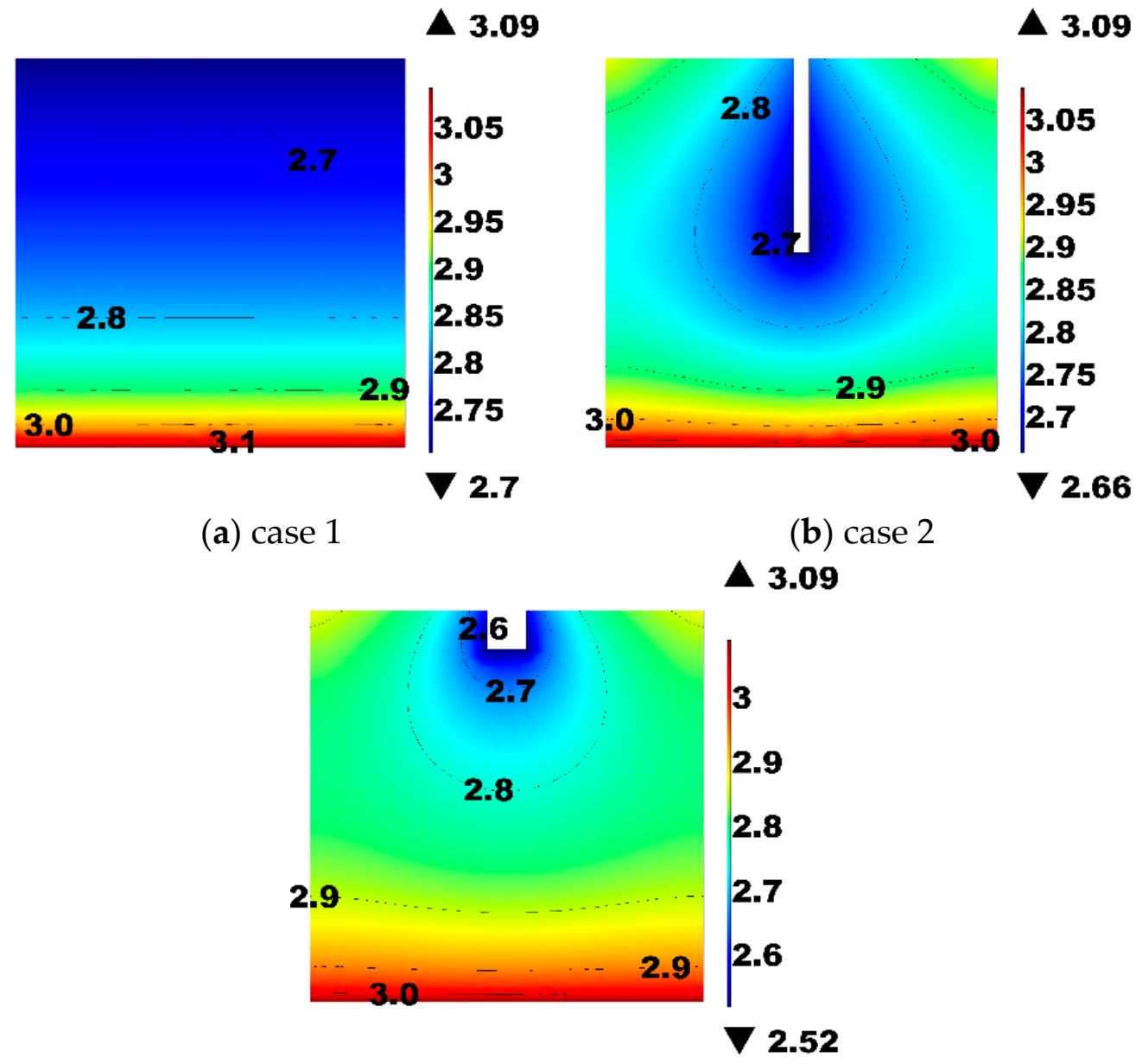

(c) case 3

Figure 2. C/L of MSW after $1000 \mathrm{~d}$ of leachate recirculation.

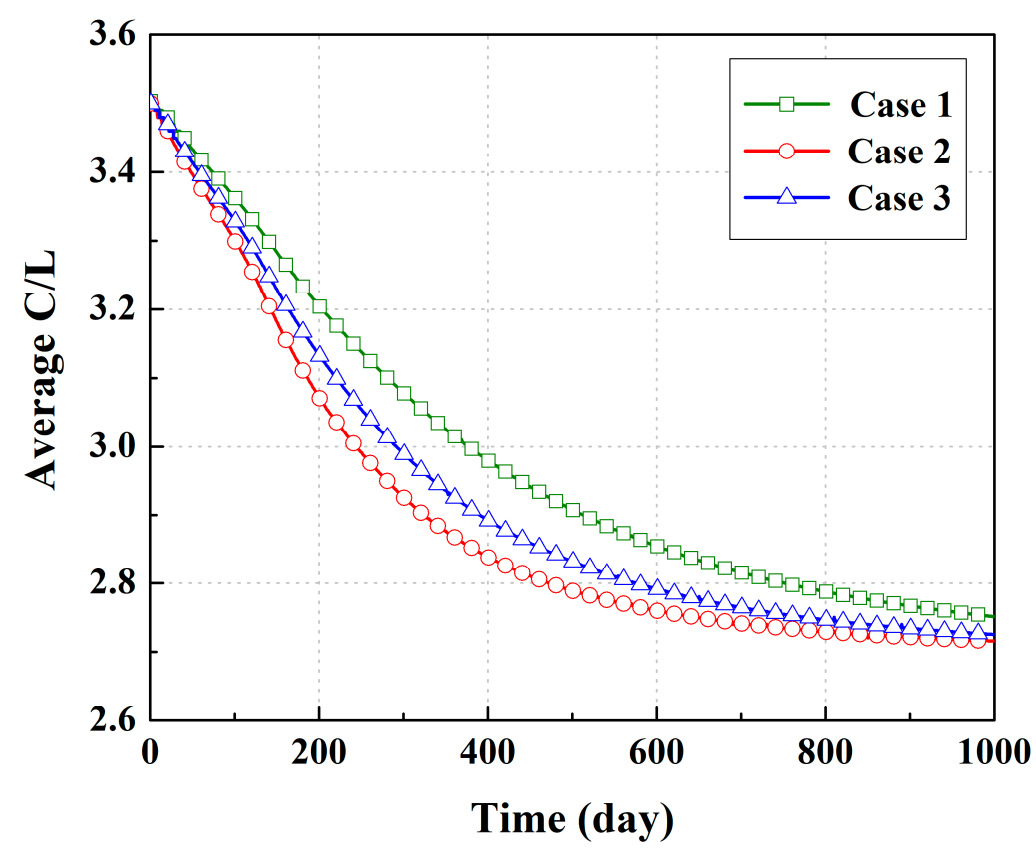

Figure 3. Average C/L of MSW below the leachate recirculation system. 


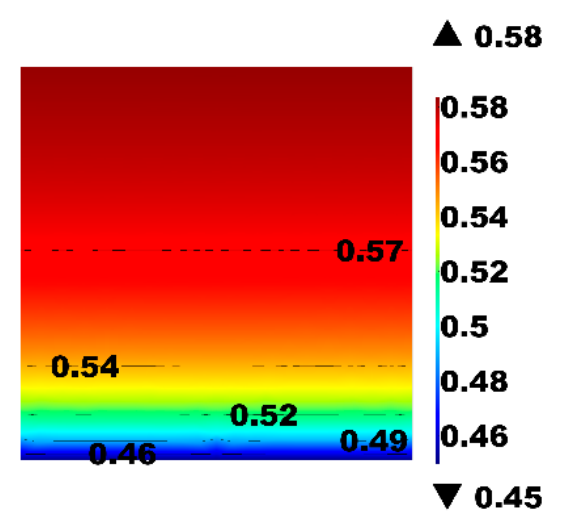

(a) case 1

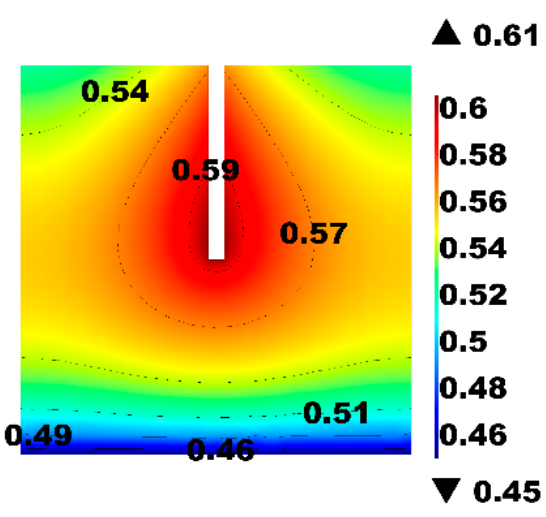

(b) case 2

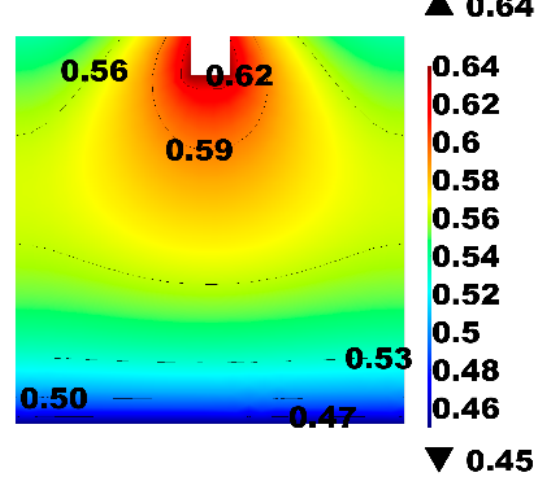

(c) case 3

Figure 4. Saturation of MSW after $200 \mathrm{~d}$ of leachate recirculation.

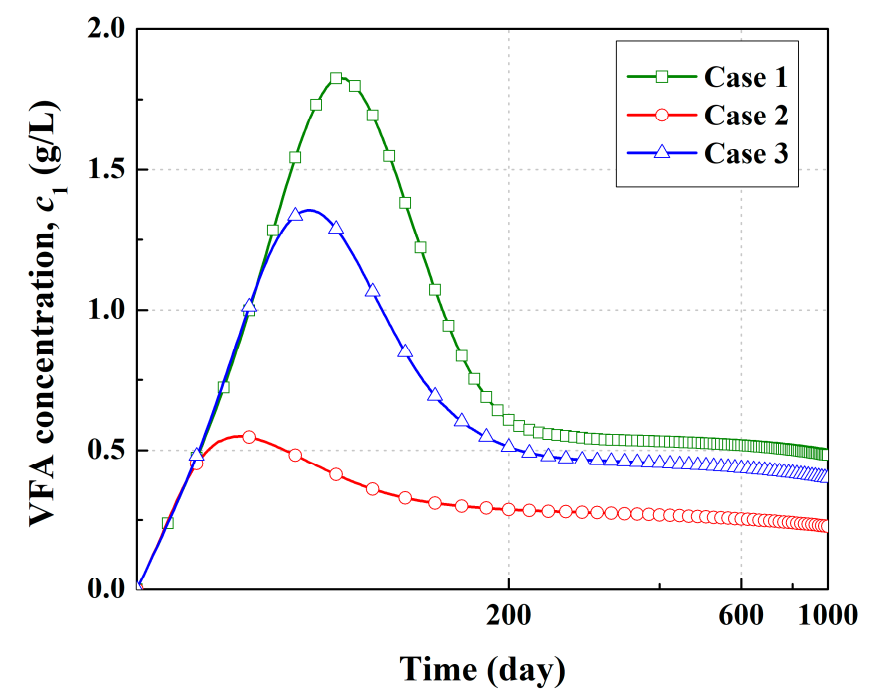

Figure 5. VFA concentration in leachate.

VFA concentration calculation results were compared with the results of a pilot-scale test [53] and laboratory-scale test [54], respectively. It can be seen from Figure 6 that the peak value and variation pattern of VFA concentration calculated by the HBM-coupled model are close to the experimental results. Due to the different conditions of leachate recirculation, the peak concentration of VFA in the simulation results is different from the measured data of Huang et al. Affected by the size of the laboratory test sample, the recirculated leachate reached the bottom of the sample earlier in Xu's test; thus, the VFA concentration for the laboratory test increased faster in the early stage of recirculation. 


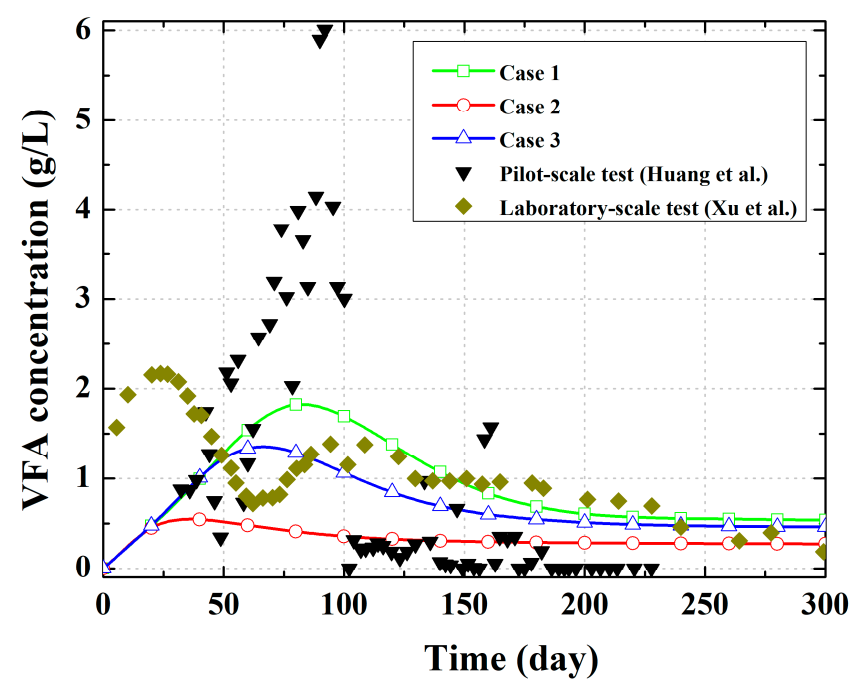

Figure 6. Validation of VFA concentration calculation results.

\subsection{Landfill Gas Generation}

A large amount of methanogen is introduced into landfills by injection of treated leachate, which accelerates the methanogenesis reaction in the stabilization process of landfills significantly. Pore gas pressure in landfills increases with the rapid generation of landfill gas within $100 \mathrm{~d}$ (Figure 7). Taking the variation in pore pressure at a depth of $8 \mathrm{~m}$ in landfills (below the leachate recirculation systems, points $A_{1,2,3}$ in Figure 1 ) as an example, it is observed that case 2 has the highest pore gas pressure at the first $50 \mathrm{~d}$. The increase of pore gas pressure slows down after $100 \mathrm{~d}$, which means the landfill gas generation has entered a stable stage for all three cases. The leachate injected or generated by hydrolysis reaction will flow to the drainage system at bottom of landfills, high saturation will impede the transport of landfill gas, which results in a significant increase of pore gas pressure in landfills. The pore gas pressure at the bottom of landfills exceeds $30 \mathrm{kPa}$ in all three cases at $600 \mathrm{~d}$ (see Figure 8). The vertical well can provide a drainage channel for the MSW inside the landfill; however, landfill gas has to transport a longer distance to dissipate the pore gas pressure in cases 1 and 3. Therefore, the bioreactor landfill using a vertical well has the lowest pore gas pressure after $100 \mathrm{~d}$. It is recommended to collect landfill gas by active air extraction during leachate recirculation to avoid the adverse effects of high pore gas pressure on the slope stability of landfills [34].

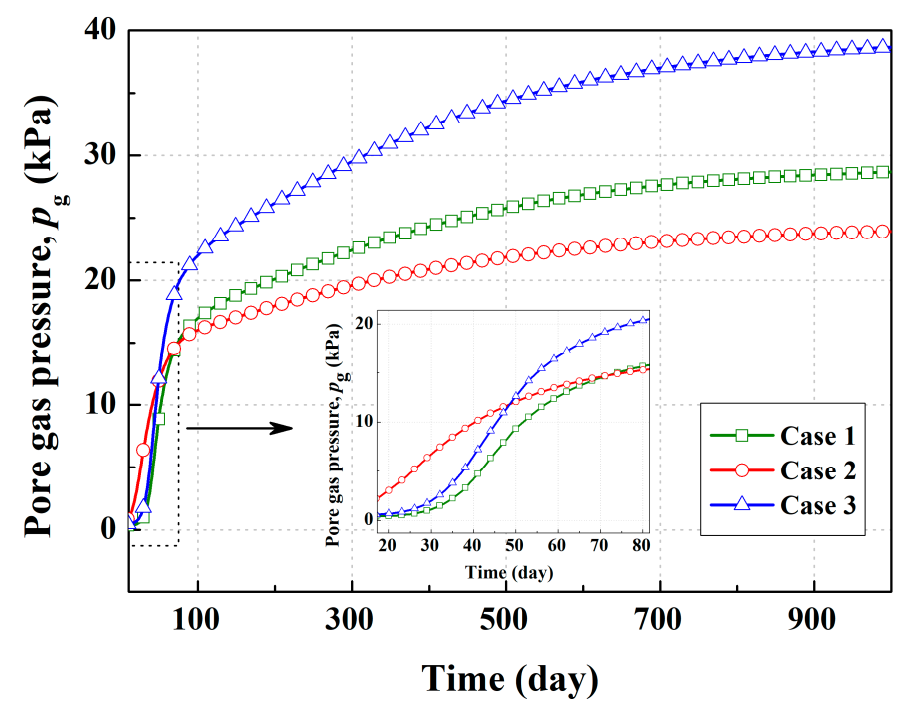

Figure 7. Pore gas pressure at the depth of $8 \mathrm{~m}$ in the landfill cell. 


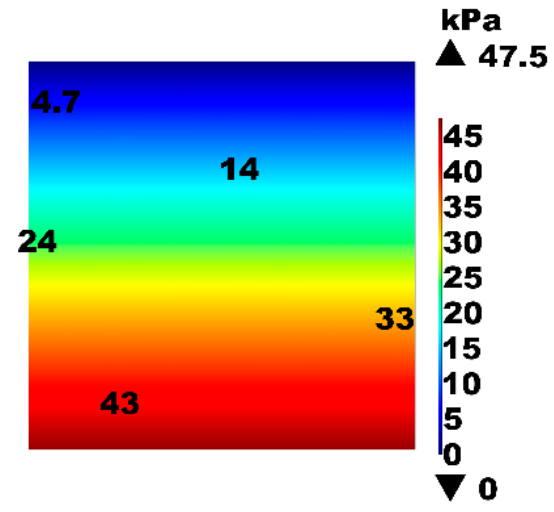

(a) case 1

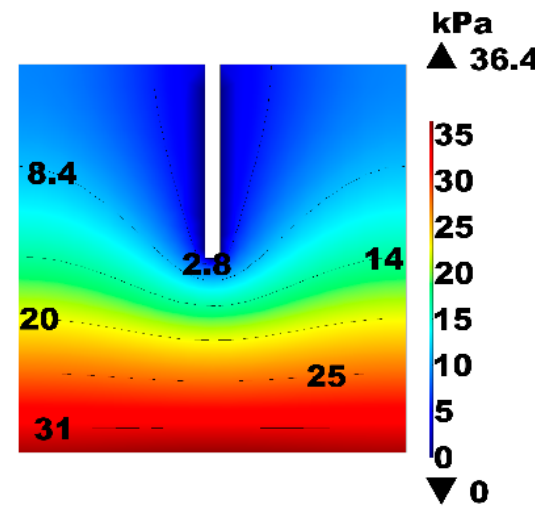

(b) case 2

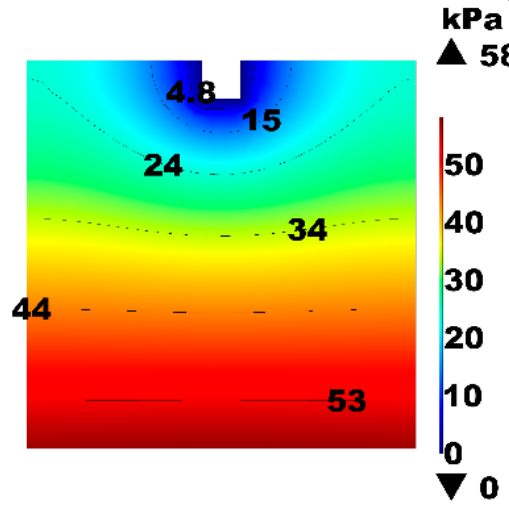

(c) case 3

Figure 8. Pore gas pressure distribution in landfill cell after $600 \mathrm{~d}$ of leachate recirculation.

A large-scale bioreactor experiment by using high food waste content MSW was carried out by Zhan et al. [3,54]. The leachate drawdown and recirculation started on $346 \mathrm{~d}$ and pore gas pressure was measured during leachate recirculation. It can be seen in Figure 9 that pore gas pressure increases rapidly with leachate refilling, and the calculation results of pore gas pressure are close to the measured maximum pore gas pressure. The pore gas pressure is dissipated due to leachate drawdown in the experiment, which is different from the three cases. The continuous recirculation of leachate leads to a slow rise in pore gas pressure in a later stage.

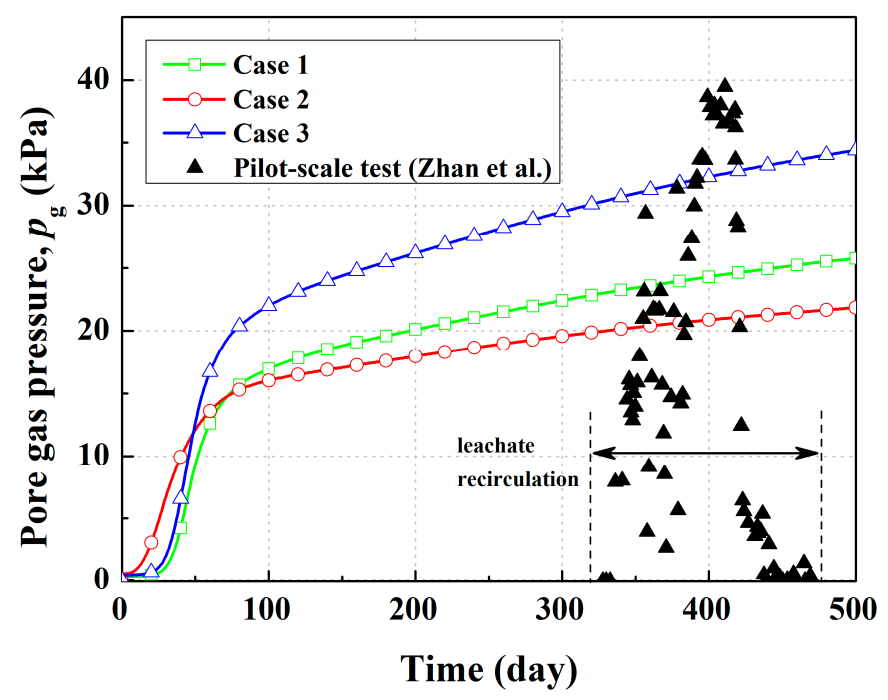

Figure 9. Validation of pore gas pressure calculation results. 


\subsection{Settlement of Landfill Cells}

Figure 10 indicates the settlement process of top surfaces of landfills (points $B_{1,2,3}$ in Figure 1). The fast hydrolysis of degradable components leads to a mass loss of MSW solid skeleton, which changes the mechanical properties of MSW significantly. An obvious degradation settlement occurs in landfills due to leachate recirculation. The settlement rates are fast in the initial $500 \mathrm{~d}$ for all three cases and gradually decreased after $500 \mathrm{~d}$. The degradation compression is completed nearly $1000 \mathrm{~d}$, and the maximum long-term settlement of three cases is close, which is about $1.26 \mathrm{~m}$. Case 2 has the fastest settlement rate among the three cases; it takes about $304 \mathrm{~d}$ for case 2 to complete $1 \mathrm{~m}$ of settlement, which means the compression strain in the landfill is $10 \%$. However, it needs $478 \mathrm{~d}$ and $396 \mathrm{~d}$ to reach the same compression in cases 1 and 3, respectively. The calculation results of longterm compression strain are in good agreement with the laboratory tests of $\mathrm{Xu}$ et al. [54] (Figure 11). It is worth noting that the difference in the degradation degree of MSW will lead to differential settlements in landfills, as shown in Figure 12. For case 2, the maximum differential settlement is $0.23 \mathrm{~m}$ at $350 \mathrm{~d}$, which is $21.7 \%$ of the compression at point $B_{2}$, while the maximum differential settlement of case 3 is $0.23 \mathrm{~m}$ at the same time, which is $22.8 \%$ of the compression at point $B_{3}$. The obvious differential settlement caused by leachate recirculation in short term may lead to a failure of landfill infrastructures, such as cover systems, leachate collection and drainage systems, and landfill gas collection systems. Reinforcement measures are recommended to keep the integrity of landfill infrastructures from a potential differential settlement.

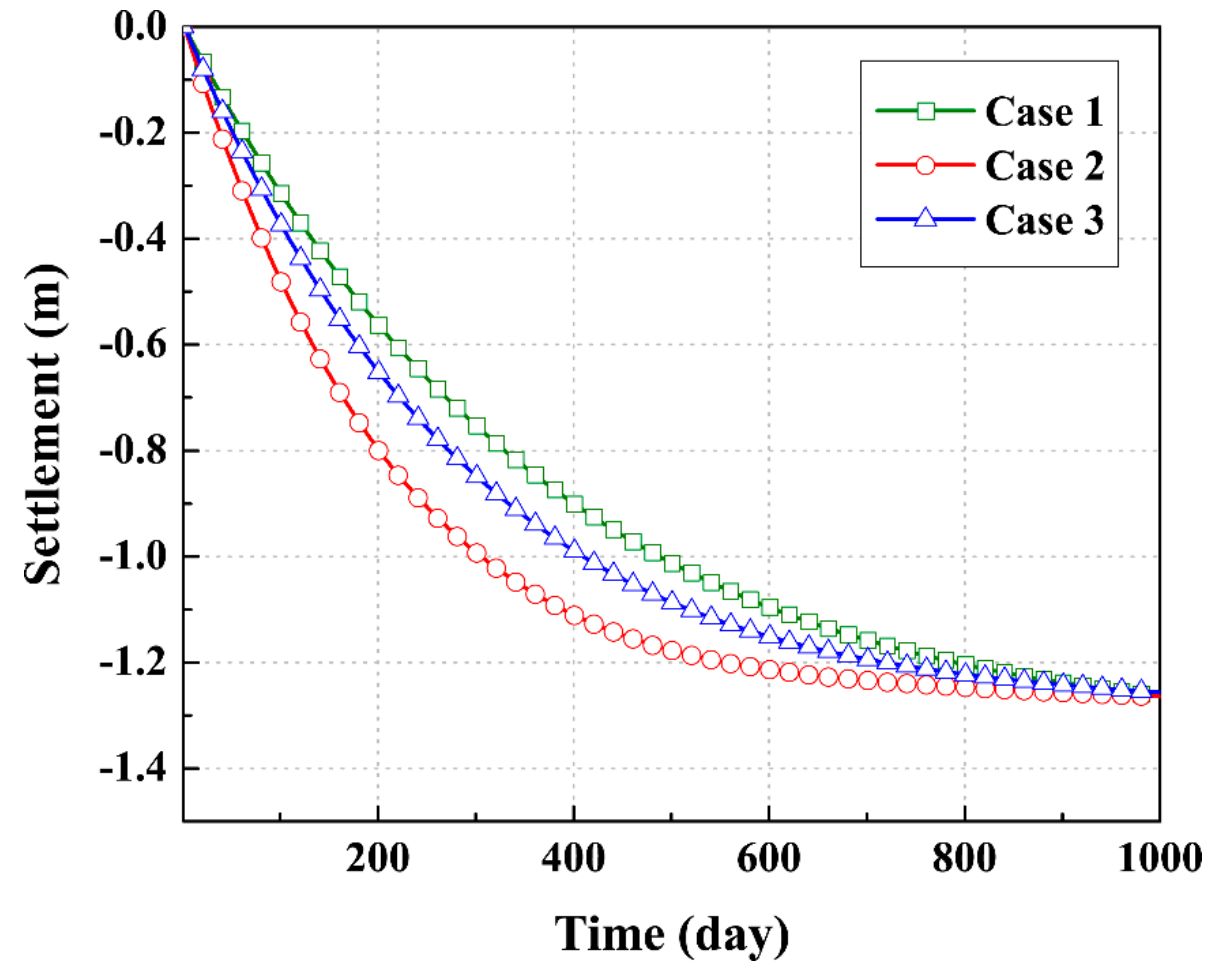

Figure 10. Stabilization process of settlement in landfill. 


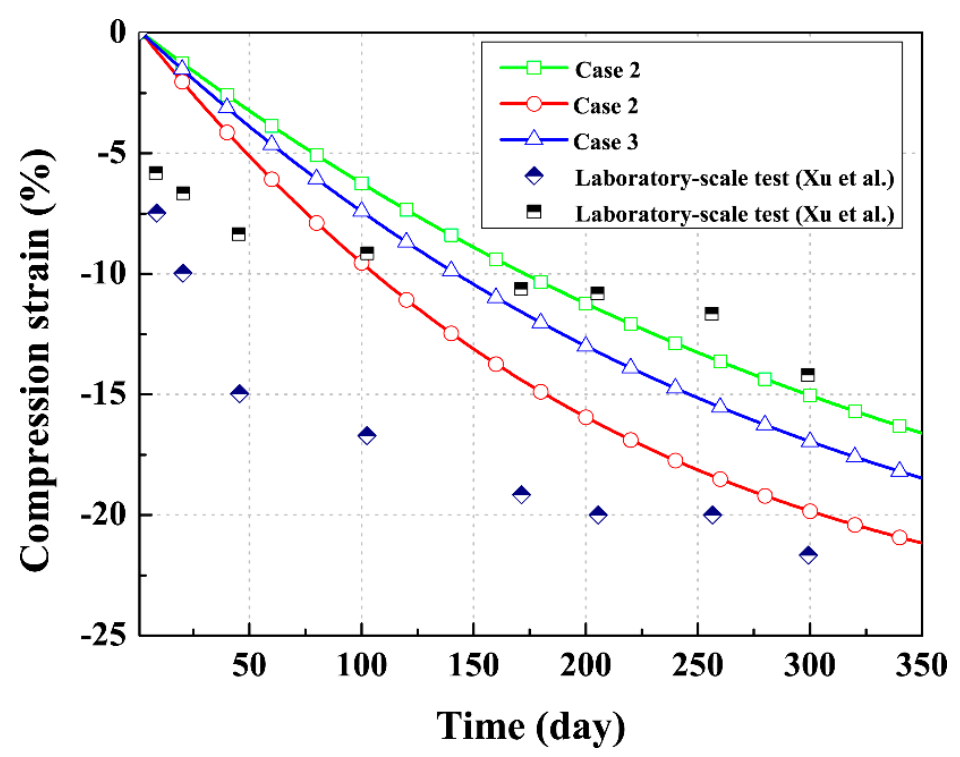

Figure 11. Validation of compression strain calculation results.

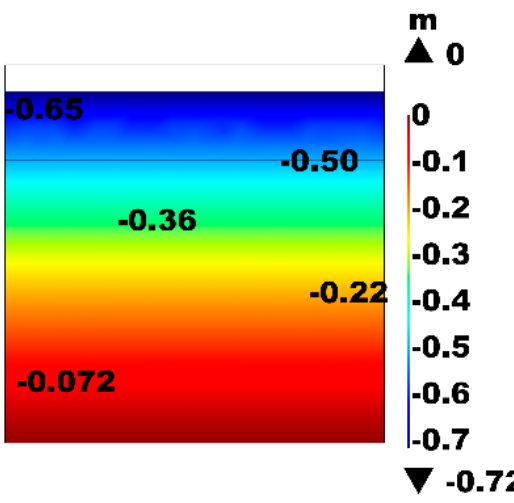

(a) case 1

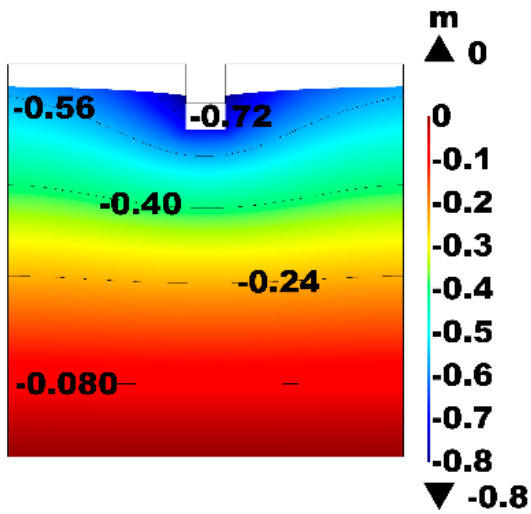

(c) case 3

m

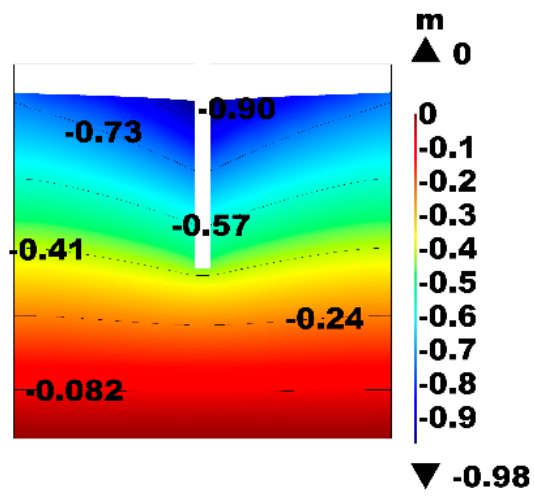

(b) case 2 
(1) The coupled model proposed in this study can well consider the hydraulic behaviors of LR in a BL by considering the fast hydrolysis of kitchen waste and leachate generation due to intraparticle water release at the early stage of the stabilization process. This model enables the investigation of the distribution of leachate and gas in a landfill, providing useful information for the design of the LR system in bioreactor landfills.

(2) Recirculation of leachate has significant effects on accelerating the decomposition of MSW with high kitchen waste content, which can also remove VFA in leachate, promote landfill gas generation, and increase the early settlement in landfills. However, leachate recirculation may lead to a significant increase in pore gas pressure and obvious differential settlement in landfills. Active air extraction and reinforcement of landfill infrastructures are recommended to avoid the adverse effects of LR.

(3) When the daily amount of leachate injection is certain, the vertical well can mitigate the rapid accumulation of pore gas pressure in the landfill during the stable period of landfill gas generation but has the fastest settlement rate, compared to the surface spraying and horizontal trench. The closer MSW is to the LR system, the more obvious the effect will be of the leachate injection.

Author Contributions: Conceptualization, H.L. (Hailong Liu) and Z.H.; methodology, H.L. (Hao Lv); software, X.J., P.Z. and Z.H.; validation, X.J., C.C. and P.Z.; formal analysis, C.C.; investigation, H.L. (Hailong Liu) and X.J.; resources, Z.H.; data curation, H.L. (Hao Lv); writing-original draft preparation, H.L. (Hailong Liu); writing-review and editing, P.Z., X.J. and C.C.; visualization, Z.H., P.Z. and H.L. (Hao Lv); supervision, H.L. (Hailong Liu) and P.Z.; project administration, H.L. (Hailong Liu), P.Z. and C.C.; funding acquisition, H.L. (Hailong Liu). All authors have read and agreed to the published version of the manuscript.

Funding: This research was funded by the National Natural Science Foundation of China (NSFC), Grant Number 52008071 and 51808092; the Natural Science Foundation of Liaoning Province, Grant Number 2019ZD0150; and the United Navigation Foundation of Liaoning Province, Grant Number 2020-HYLH-48.

Institutional Review Board Statement: Not applicable.

Informed Consent Statement: Not applicable.

Data Availability Statement: Data sharing is not applicable to this article.

Conflicts of Interest: The authors declare that they have no conflict of interest.

\section{References}

1. Laner, D.; Crest, M.; Scharff, H.; Morris, J.W.; Barlaz, M.A. A review of approaches for the long-term management of municipal solid waste landfills. Waste Manag. 2012, 32, 498-512. [CrossRef]

2. Rich, C.; Gronow, J.; Voulvoulis, N. The potential for aeration of MSW landfills to accelerate completion. Waste Manag. 2008, 28, 1039-1048. [CrossRef]

3. Zhan, L.T.; Xu, H.; Chen, Y.M. Biochemical, hydrological and mechanical behaviors of high food waste content MSW landfill, preliminary findings from a large-scale experiment. Waste Manag. 2017, 63, 27-40. [CrossRef]

4. Hussain, E.; Al-Ameen, J. Effect of Leachate Recirculation on Biological Stability of Municipal Solid Waste Under Simi-Arid Conditions. Al-Qadisiyah J. Eng. Sci. 2019, 12, 79-83. [CrossRef]

5. Ritter, W.F. The History and Challenges of Wastewater Reuse in Delaware and Maryland. In Proceedings of the World Environmental and Water Resources Congress 2020: Water Resources Planning and Management and Irrigation and Drainage, Reston, VA, USA, 17-21 May 2020; pp. 109-120.

6. Cui, C.Y.; Meng, K.; Xu, C.S. Analytical solution for longitudinal vibration of a floating pile in saturated porous media based on a fictitious saturated soil pile model. Comput. Geotech. 2021, 131, 103942. [CrossRef]

7. Bilgili, M.S.; Demir, A.; Özkaya, B. Influence of leachate recirculation on aerobic and anaerobic decomposition of solid wastes. J. Hazard. Mater. 2007, 143, 177-183. [CrossRef] [PubMed]

8. Sohoo, I.; Ritzkowski, M.; Kuchta, K. Influence of moisture content and leachate recirculation on oxygen consumption and waste stabilization in post aeration phase of landfill operation. Sci. Total Environ. 2021, 773, 145584. [CrossRef] [PubMed]

9. Sun, Y.; Sun, X.; Zhao, Y. Comparison of semi-aerobic and anaerobic degradation of refuse with recirculation after leachate treatment by aged refuse bioreactor. Waste Manag. 2011, 31, 1202-1209. [CrossRef] 
10. White, J.K.; Beaven, R.P.; Powrie, W. Leachate recirculation in a landfill, Some insights obtained from the development of a simple 1-D model. Waste Manag. 2011, 31, 1210-1221. [CrossRef] [PubMed]

11. Chung, J.; Kim, S.; Baek, S. Acceleration of aged-landfill stabilization by combining partial nitrification and leachate recirculation, A field-scale study. J. Hazard. Mater. 2015, 285, 436-444. [CrossRef] [PubMed]

12. Barlaz, M.A.; Ham, R.K.; Schaefer, D.M. Microbial, chemical and methane production characteristics of anaerobically decomposed refuse with and without leachate recycling. Waste Manag. Res. 1992, 10, 257-267. [CrossRef]

13. Chan, G.Y.S.; Chu, L.M.; Wong, M.H. Effects of leachate recirculation on biogas production from landfill co-disposal of municipal solid waste, sewage sludge and marine sediment. Environ. Pollut. 2002, 118, 393-399. [CrossRef]

14. Mehta, R.; Barlaz, M.A.; Yazdani, R. Refuse decomposition in the presence and absence of leachate recirculation. J. Environ. Eng. 2002, 128, 228-236. [CrossRef]

15. Demir, A.; Bilgili, M.S.; Ozkaya, B. Effect of leachate recirculation on refuse decomposition rates at landfill site, a case study. Int. J. Environ. Pollut. 2004, 21, 175-187. [CrossRef]

16. Meng, K.; Cui, C.Y.; Liang, Z.M. A new approach for longitudinal vibration of a large-diameter floating pipe pile in vis-co-elastic soil considering the three-dimensional wave effects. Comput. Geotech. 2020, 128, 103840. [CrossRef]

17. Chen, G.; Sun, Y.; Xu, Z. Assessment of Shallow Groundwater Contamination Resulting from a Municipal Solid Waste Landfill-A Case Study in Lianyungang, China. Water 2019, 11, 2496. [CrossRef]

18. Jiang, G.; Liu, D.; Chen, W. Impact of landfill density on transport and hydraulic characteristics of recirculated leachate. Environ. Technol. 2019, 40, 2310-2316. [CrossRef] [PubMed]

19. Top, S.; Akkaya, G.K.; Demir, A. Investigation of Leachate Characteristics in Field-Scale Landfill Test Cells. Int. J. Environ. Res. 2019, 13, 829-842. [CrossRef]

20. Feng, S.J.; Cao, B.Y.; Xie, H.J. Modeling of leachate recirculation using spraying-vertical well systems in bioreactor landfills. Int. J. Geomech. 2017, 17, 04017012. [CrossRef]

21. Townsend, T.G.; Wise, W.R.; Jain, P. One-dimensional gas flow model for horizontal gas collection systems at municipal solid waste landfills. J. Environ. Eng. 2005, 131, 1716-1723. [CrossRef]

22. Meng, K.; Cui, C.Y.; Li, H.J. An Ontology Framework for Pile Integrity Evaluation Based on Analytical Methodology. IEEE Access 2020, 99, 72158-72168. [CrossRef]

23. Fabbricino, M. Evaluating operational vacuum for landfill biogas extraction. Waste Manag. 2007, 27, 1393-1399. [CrossRef] [PubMed]

24. Ritter, W.F.; Chitikela, S.R. The Mississippi River Basin Phosphorus Problem: Past History and Future Challenges to Solve It. In Proceedings of the World Environmental and Water Resources Congress 2019: Watershed Management, Irrigation and Drainage, and Water Resources Planning and Management, Reston, VA, USA, 19-23 May 2019; pp. 361-373.

25. Khire, M.V.; Mukherjee, M. Leachate injection using vertical wells in bioreactor landfills. Waste Manag. 2007, $27,1233-1247$. [CrossRef] [PubMed]

26. Jain, P.; Townsend, T.G.; Tolaymat, T.M. Steady-state design of vertical wells for liquids addition at bioreactor landfills. Waste Manag. 2010, 30, 2022-2029. [CrossRef]

27. Reddy, K.R.; Kumar, G.; Giri, R.K. Influence of dynamic coupled hydro-bio-mechanical processes on response of municipal solid waste and liner system in bioreactor landfills. Waste Manag. 2017, 63, 143-160. [CrossRef]

28. Feng, S.J.; Lu, S.F.; Chen, H.X. Three-dimensional modelling of coupled leachate and gas flow in bioreactor landfills. Comput. Geotech. 2017, 84, 138-151. [CrossRef]

29. White, J.; Robinson, J.; Ren, Q. Modelling the biochemical degradation of solid waste in landfills. Waste Manag. 2004, 24, 227-240. [CrossRef] [PubMed]

30. De Cortázar, A.L.G.; Lantarón, J.H.; Fernández, O.M.; Monzón, I.T.; Lamia, M.F. Modelling for environmental assessment of municipal solid waste landfills (Part II: Biodegradation). Waste Manag. Res. 2002, 20, 514-528. [CrossRef] [PubMed]

31. Wdowczyk, A.; Szymańska-Pulikowska, A. Differences in the Composition of Leachate from Active and Non-Operational Municipal Waste Landfills in Poland. Water 2020, 12, 3129. [CrossRef]

32. Dho, N.Y.; Koo, J.K.; Lee, S.R. Prediction of leachate level in Kimpo metropolitan landfill site by total water balance. Environ. Monit. Assess. 2002, 73, 207-219. [CrossRef] [PubMed]

33. Feng, S.J.; Chen, Z.W.; Chen, H.X. Slope stability of landfills considering leachate recirculation using vertical wells. Eng. Geol. 2018, 241, 76-85. [CrossRef]

34. Merry, S.M.; Kavazanjian, J.E.; Fritz, W.U. Reconnaissance of the July 10, 2000, Payatas landfill failure. J. Perform. Constr. Facil. 2005, 19, 100-107. [CrossRef]

35. Ritter, W.F. Progress on the Chesapeake Bay TMDL and Challenges in Meeting the 2025 Pollution-Reduction Loads. In Proceedings of the World Environmental and Water Resources Congress 2019: Watershed Management, Irrigation and Drainage, and Water Resources Planning and Management, Reston, VA, USA, 19-23 May 2019; pp. 63-70.

36. Van Genuchten, M.T. A closed-form equation for predicting the hydraulic conductivity of unsaturated soils. Soil Sci. Soc. Am. J. 1980, 44, 892-898. [CrossRef]

37. Zhang, H.; Li, Z.; Xu, H. Coupled Analysis of Leachate Recirculation and Heat Transfer for a Landfill with Buried Waste Tyres. Open Civ. Eng. J. 2018, 12, 290-300. [CrossRef]

38. Barlaz, M.A. Forest products decomposition in municipal solid waste landfills. Waste Manag. 2006, 26, 321-333. [CrossRef] 
39. McDougall, J. A hydro-bio-mechanical model for settlement and other behaviour in landfilled waste. Comput. Geotech. 2007, 34, 229-246. [CrossRef]

40. Chen, Y.M. A fundamental theory of environmental geotechnics and its application. Chin. J. Geotech. Eng. 2014, 36, 1-46.

41. Liu, H.; Luo, X.; Jiang, X. The Evaluation System of the Sustainable Development of Municipal Solid Waste Landfills and Its Application. Sustainability 2021, 13, 1150. [CrossRef]

42. Vavilin, V.A.; Rytov, S.V.; Lokshina, L.Y.; Pavlostathis, S.G.; Barlaz, M.A. Distributed model of solid waste anaerobic digestion: Effects of leachate recirculation and $\mathrm{pH}$ adjustment. Biotechnol. Bioeng. 2003, 81, 66-73. [CrossRef]

43. Xu, H.; Wang, J.; Zhan, L. Characterization of compression behaviors of high food waste content (HFWC) MSW and no food waste content (NFWC) MSW in China. Waste Manag. 2020, 103, 305-313. [CrossRef]

44. Chen, Y.; Ke, H.; Fredlund, D.G. Secondary compression of municipal solid wastes and a compression model for predicting settlement of municipal solid waste landfills. J. Geotech. Geoenvironmental. Eng. 2010, 136, 706-717. [CrossRef]

45. He, P.J.; Qu, X.; Shao, L.M. Leachate pretreatment for enhancing organic matter conversion in landfill bioreactor. J. Hazard. Mater. 2007, 142, 288-296. [CrossRef] [PubMed]

46. Meima, J.A.; Naranjo, N.M.; Haarstrick, A. Sensitivity analysis and literature review of parameters controlling local biodegradation processes in municipal solid waste landfills. Waste Manag. 2008, 28, 904-918. [CrossRef] [PubMed]

47. Chen, Y.M.; Guo, R.Y.; Li, Y.C. A degradation model for high kitchen waste content municipal solid waste. Waste Manag. 2016, 58, 376-385. [CrossRef] [PubMed]

48. Xu, X.B.; Zhan, L.T.; Chen, Y.M. Intrinsic and relative permeabilities of shredded municipal solid wastes from the Qizishan landfill. Can. Geotech. J. 2014, 51, 1243-1252. [CrossRef]

49. Li, Y.C.; Liu, H.L.; Cleall, P.J. Influences of operational practices on municipal solid waste landfill storage capacity. Waste Manag. Res. 2013, 31, 273-282. [CrossRef] [PubMed]

50. Gao, W.; Bian, X.C.; Xu, W.J.; Chen, Y.M. Storage Capacity and Slope Stability Analysis of Municipal Solid Waste Landfills. J. Perform. Constr. Facil. 2018, 32, 04018036. [CrossRef]

51. Liu, J.L.; Ke, H.; Zhan, L.T.; Chen, Y.M. Simulation tests of biodegradation and compression of municipal solid waste. In Proceedings of the International Symposium on Geoenvironmental Engineering, Hangzhou, China, 8-10 September 2009; pp. 521-524.

52. Chen, Y.M.; Xu, W.J.; Ling, D.S. A degradation-consolidation model for the stabilization behavior of landfilled municipal solid waste. Comput. Geotech. 2020, 118, 103341. [CrossRef]

53. Huang, W.; Wang, Z.; Guo, Q.; Wang, H.; Zhou, Y.; Ng, W.J. Pilot-scale landfill with leachate recirculation for enhanced stabilization. Biochem. Eng. J. 2016, 105, 437-445. [CrossRef]

54. Xu, Q.; Tian, Y.; Wang, S.; Ko, J.H. A comparative study of leachate quality and biogas generation in simulated anaerobic and hybrid bioreactors. Waste Manag. 2015, 41, 94-100. [CrossRef] [PubMed] 